\title{
Importance of Cyclophosphamide-induced Bystander Effect on T Cells for a Successful Tumor Eradication in Response to Adoptive Immunotherapy in Mice
}

\author{
Enrico Proietti, Giampaolo Greco, Beatrice Garrone, Sara Baccarini, Claudia Mauri, Massimo Venditti, Davide Carlei, \\ and Filippo Belardelli \\ Laboratory of Virology, Istituto Superiore di Sanità, Rome 00161, Italy
}

\begin{abstract}
Cyclophosphamide (CTX) increases the antitumor effectiveness of adoptive immunotherapy in mice, and combined immunotherapy regimens are now used in some clinical trials. However, the mechanisms underlying the synergistic antitumor responses are still unclear. The purpose of this study was (a) to evaluate the antitumor response to CTX and adoptive immunotherapy in mice bearing four different syngeneic tumors (two responsive in vivo to CTX and two resistant); and (b) to define the mechanism(s) of the CTXimmunotherapy synergism. Tumor-bearing DBA/2 mice were treated with a single injection of CTX followed by an intravenous infusion of tumor-immune spleen cells. In all the four tumor models, a single CTX injection resulted in an impressive antitumor response to the subsequent injection of spleen cells from mice immunized with homologous tumor cells independently of the in vivo response to CTX alone. Detailed analysis of the antitumor mechanisms in mice transplanted with metastatic Friend leukemia cells revealed that $(a)$ the effectiveness of this combined therapy was dependent neither on the CTX-induced reduction of tumor burden nor on CTX-induced inhibition of some putative tumor-induced suppressor cells; $(b)$ the CTX/immune cells' regimen strongly protected the mice from subsequent injection of FLC, provided the animals were also preinoculated with inactivated homologous tumor together with the immune spleen cells; (c) $\mathrm{CD}^{+}{ }^{+} \mathrm{T}$ immune lymphocytes were the major cell type responsible for the antitumor activity; $(d)$ the combined therapy was ineffective in mice treated with antiasialo-GM $\mathrm{GM}_{1}$ or anti-IFN- $\alpha / \beta$ antibodies; $(e)$ spleen and/ or bone marrow cells from CTX-treated mice produced soluble factors that assisted in proliferation of the spleen cells. Altogether, these results indicate that CTX acts via bystander effects, possibly through production of $\mathrm{T}$ cell growth factors occurring during the rebound events after drug administration, which may sustain the proliferation, survival, and activity of the transferred immune $\mathrm{T}$ lymphocytes. Thus, our findings indicate the need for reappraisal of the mechanisms
\end{abstract}

Address correspondence to Enrico Proietti, M.D., Laboratory of Virology, Istituto Superiore di Sanità, Viale Regina Elena 229, 00161 Rome, Italy. Phone: 39-6-49903356; FAX: 39-6-49387184; E-mail: proietti@virus1.net.iss.it

Received for publication 30 July 1997 and accepted in revised form 11 November 1997.

J. Clin. Invest.

(C) The American Society for Clinical Investigation, Inc. 0021-9738/98/01/0429/13 \$2.00

Volume 101, Number 2, January 1998, 429-441

http://www.jci.org underlying the synergistic effects of CTX and adoptive immunotherapy, and may provide new insights into the definition of new and more effective strategies with chemotherapy and adoptive immunotherapy for cancer patients. (J. Clin. Invest. 1998. 101:429-441.) Key words: cyclophosphamide • adoptive immunotherapy • interferon type $\mathrm{I} \bullet$ tumors $\bullet$ mouse

\section{Introduction}

Over the last decade, much attention has been given to adoptive immunotherapy as a possible therapeutic strategy for treatment of certain human tumors $(1,2)$. The interest in this therapeutic approach has originated from numerous reports describing a successful T cell-mediated adoptive immunotherapy of established immunogenic tumors in mice (3-6). However, in spite of the remarkable results obtained in certain mouse tumor models and some encouraging responses observed in a few clinical trials, little is known about the fate of the transferred immune cells or the optimal strategies for enhancing their survival and antitumor activity after immune cell infusions. In particular, one major issue is whether the effectiveness of adoptive immunotherapy can be improved by combining this approach with other regimens currently used in cancer therapy.

Cyclophosphamide $(\mathrm{CTX})^{1}$ is a widely used chemotherapeutic agent in cancer therapy (for review see reference 7). CTX has also been used by several groups as an immunomodulatory agent against murine and human tumors (8-22). Many studies have reported that CTX can increase the efficacy of immunotherapeutic regimens by removing tumor-induced suppressor T cells (23-28). Although the nature of these suppressor cells is still not fully defined, combined regimens with CTX and immunotherapy are now used in some clinical trials with cancer patients (29-31). Therefore, it is important to revisit the issue of the possible mechanisms underlying the antitumor activity of combined regimens with CTX and immunotherapy since a better knowledge of these mechanisms in experimental tumor models should lead to more effective use of these therapeutic strategies in cancer patients.

We previously demonstrated that four different tumors, all transplantable into syngeneic DBA/2 mice, exhibited qualitative differences in their in vivo response to CTX: CTX inhibited tumor growth in mice transplanted with two highly metastatic tumor cell lines (i.e., FLC and the ESb lymphoma), while it was totally ineffective (or even induced adverse effects) in animals bearing two immunogenic tumors highly responsive to IL-2 therapy (the Eb and p11-R-Eb lymphomas; 32).

In this study, we first evaluated whether injecting CTX in DBA/2 mice bearing the abovementioned established syngeneic tumors could render the animals responsive (or more responsive) to inoculation of spleen cells from donor mice im-

1. Abbreviation used in this paper: CTX, cyclophosphamide. 
munized with homologous tumor cells. The data reported herein indicate that a single inoculation of CTX resulted in a dramatic antitumor response to subsequent injection of the immune spleen cells in all the four tumor models. Studies aimed at defining the mechanisms involved in this potent synergistic response in the FLC tumor system revealed that CTX did not act by inhibiting some putative suppressor cells. Instead, it primed the host for an optimal antitumor response to the subsequent transfer of the sensitized immune spleen cells through induction of bystander effects (i.e., production of growth factors normally occurring as a homeostatic response after the chemotherapy), which may sustain proliferation, survival, and activity of the immune $\mathrm{T}$ lymphocytes. CD4+ T lymphocytes proved to be the important cell component in the transferred immune cell population. Moreover, an ensemble of experiments indicated that an intact immune system of the recipient host and some soluble factors (IFN- $\alpha / \beta$ ) were essential in mediating the antitumor response to the adoptive immunotherapy in the CTX-injected animals. Altogether, these results may lead to reinterpretation of the mechanisms underlying the synergistic effects of CTX and adoptive immunotherapy observed in various experimental tumor models by others (8-22), largely explained on the assumption of a selective effect of CTX on "suppressor T cells" (24, 26-28).

\section{Methods}

Mice. Six 8-wk-old male DBA/2 and nude (CD1 background) mice were obtained from Charles River Breeding Laboratories (Calco, Italy). SIA nude mice were prepared as previously described (33) and maintained in special sterile facilities. All mice were treated in accordance with the European Community guidelines.

Tumor cells. IFN $\alpha / \beta$-resistant 3Cl-8 FLC (34) were serially passaged intraperitoneally in syngeneic DBA/2 mice. FLC are highly metastatic to the liver and the spleen after intravenous subcutaneous injection in DBA/2 mice. Eb and ESb cells were provided by Dr. V. Schirrmacher (Heidelberg, Germany). Eb cells are nonmetastatic lymphoma cells (35). They were cultivated in vitro in RPMI-1640 supplemented with $10 \%$ FCS and $1 \mathrm{mM}$ Hepes (complete medium). The ESb lymphoma is an in vivo-selected variant of Eb lymphoma (35). Subcutaneous injection of DBA/2 mice with ESb cells results in development of small tumors that rapidly metastasize to the liver after 3-4 d. These cells were serially passaged intraperitoneally in syngeneic DBA/2 mice. p11-R-Eb cells were obtained in our laboratory after 11 intraperitoneal passages of the original $\mathrm{Eb}$ cells in syngeneic DBA/2 mice and were cryopreserved in RPMI-1640, 20\% FCS and $10 \%$ dimethylsulfoxide in liquid $\mathrm{N}_{2}$. p11-R-Eb cells metastasize to the liver after intravenous or subcutaneous injection (36).

CTX (Sigma Chemical Co., St. Louis, MO) was freshly diluted in physiologic solution and injected intraperitoneally in $0.5 \mathrm{ml}$. If not otherwise stated, we used a CTX dose of $83 \mathrm{mg} / \mathrm{kg}$ body weight. This CTX dose has been proven to induce the most marked antitumor effect in mice transplanted with either FLC or ESb, without inducing any acute toxicity $(37,38)$. Control preparations consisted of physiologic solution unless otherwise stated.

Immunization of mice with different tumor cells. To immunize mice against $\mathrm{ESb}, \mathrm{Eb}$, and p11-R-Eb tumors, DBA/2 mice received two subcutaneous inocula of $2 \times 10^{7}$ irradiated tumor cells (100 Gy) at a time interval of $2 \mathrm{wk}$. To achieve an immunization against 3Cl-8 FLC, $\mathrm{DBA} / 2$ mice were injected subcutaneously with $2 \times 10^{6}$ genetically modified FLC producing IFN $\alpha 1$ (IFN $\alpha 1-\mathrm{Cl}-11 ; 39)$. These cells grow subcutaneously in DBA/2 mice before being rejected, and all the mice are resistant to a subsequent challenge with parental metastatic 3 Cl-8 FLC (39). Spleens were usually taken from these mice $24-30 \mathrm{~d}$ after the injection of the IFN-producing cells.
Preparation of formalin-fixed FLC. After irradiation, 3Cl-8 FLC are still capable of producing infectious retroviral particles. Therefore, to provide tumor antigen for some in vivo experiments, we used formalin-fixed (instead of irradiated) tumor cells. 3Cl-8 FLC were resuspended in a PBS-buffered $4 \%$ formalin solution, incubated 30 min at room temperature, and extensively washed with PBS before inoculation

Preparation of bone marrow cells and cells for adoptive transfer. Mice were killed, and spleens and tibias were removed aseptically. Bone marrow cells were derived from the tibia and passed into a 2-ml syringe through an 11-gauge needle. Single-cell suspension of spleen cells were prepared from the spleens of normal or immunized mice. Erythrocytes were lysed after a 3-min incubation at room temperature in $0.16 \mathrm{M}$ Tris-buffered $\mathrm{NH}_{4} \mathrm{Cl}$. Cells were washed in complete medium, passed through a cell strainer (Falcon 2350; Becton Dickinson, Inc., Rutherford, NJ) and resuspended to $\sim 2.5 \times 10^{8}$ viable cells/ml (determined by Trypan blue exclusion) in RPMI 1640 medium with $2 \%$ FCS immediately before inoculation.

Standard chemoimmunotherapy. $4 \mathrm{~d}$ after subcutaneous or $1 \mathrm{~d}$ after intravenous inoculation of tumor cells, mice were treated intraperitoneally with $83 \mathrm{mg} / \mathrm{kg}$ CTX in $0.5 \mathrm{ml}$ saline. $4-5 \mathrm{~h}$ later, mice were injected intravenously with $0.4 \mathrm{ml}$ of a suspension of $10^{8}$ spleen cells freshly prepared from mice immunized against the tumor or from normal or tumor-bearing mice, as described in the figure legends.

Antibodies for cell depletion and identification. Antibodies used to deplete specific cell populations were ammonium sulphate-precipitated preparations from ascitic fluid of anti $\mathrm{CD}^{+}$(GK 1.5, L3T4; American Type Culture Collection, Rockville, MD) and anti CD8 ${ }^{+}$ (TIB-5 105, Lyt 2, ATCC) hybridomas or anti asialo $\mathrm{GM}_{-1}$ serum (Wako Chemicals GmbH, Dusseldorf, Germany). Antibody treatments were performed as described elsewhere $(40,41)$. Depletion of the respective cell populations was verified by two-color flow cytometry using a FACSort cytometer (Becton Dickinson, Inc.) with the following monoclonal antibodies: anti-murine CD3 (GIBCOBRL, Gaithersburg, MD), CD4 (GIBCO-BRL), and CD8 (GIBCOBRL).

Depletion of cell populations from donor spleen cells. $\mathrm{CD}^{+}, \mathrm{CD} 8^{+}$, and NK cells were depleted in vitro by using complement-mediated cytotoxicity. Donor spleen cells were first incubated on ice with a $1 /$ 1,000 dilution of the appropriate antibody for $60 \mathrm{~min}$, and then for a further $60 \mathrm{~min}$ in a $37^{\circ} \mathrm{C}$ water bath with a $1 / 12$ dilution of low-tox rabbit complement (Cedarlane Labs, Ltd., Hornby, Ontario). After washing in RPMI 1640 with $2 \%$ FCS, cells were resuspended at $\sim 10^{8}$ cells $/ \mathrm{ml}$. In each experiment, aliquots from each cell depletion procedure were analyzed by cytofluorography to verify cell depletion.

Antibody to mouse IFN $\alpha / \beta$. Sheep antibodies to mouse IFN $\alpha / \beta$ and normal sheep Ig were a generous gift of Dr. Ion Gresser (Villejuif, France). The origin of sheep antibodies to mouse IFN $\alpha / \beta$ (sheep no. 1) and normal sheep Ig, their purification, and assay have been previously described in detail $(42,43)$.

Cocultivation of cells through semipermeable filters. $1 \mathrm{ml}$ of complete medium containing $10^{4}$ bone marrow cells and $10^{6}$ splenocytes was plated onto a microporous membrane cell culture inset (Falcon 3095; Becton Dickinson, Inc.). These membranes are specifically designed to allow cocultivation procedures with fluids and fluid component exchange without allowing a cell:cell contact. Each cell culture inset was then placed onto a corresponding well of a 24-well tray (Falcon; Becton Dickinson, Inc.) previously filled with $1 \mathrm{ml}$ of complete medium containing $10^{6}$ immune spleen cells. After a 5-d incubation at $37^{\circ} \mathrm{C}$ in a $5 \% \mathrm{CO}_{2}$ humidified incubator, cells were harvested and assayed for $\left[{ }^{3} \mathrm{H}\right]$ thymidine incorporation as described below.

$\left[{ }^{3} \mathrm{H}\right]$ Thymidine incorporation assay. $2 \times 10^{5}$ cells in $0.2 \mathrm{ml} / \mathrm{well}$ complete medium in 96 flat-bottomed well trays, were incubated at $37^{\circ} \mathrm{C}$ and harvested on day 5 after $18 \mathrm{~h}$ of culture in the presence of $0.5 \mu \mathrm{Ci} /$ well of $\left[{ }^{3} \mathrm{H}\right]$ thymidine (DuPont-NEN, Boston, MA).

Peripheral blood leukocytes count. Anesthetized animals were bled by the tail. $5 \mu \mathrm{l}$ of blood were diluted in $45 \mu \mathrm{l}$ Turk's solution, 
and white blood cells (WBC) were counted in a hemocytometer. Blood was also smeared on a glass slide and stained with May-Grunwald-Giemsa for differential blood cell count.

Statistical analyses. Data were analyzed by Wilkoxon rank-sum test.

\section{Results}

Synergistic effects of CTX and immune spleen cells in the therapy of DBA/2 mice transplanted with syngeneic tumors exhibiting a different response to $C T X$ alone. Fig. 1 shows the effects of a single injection of CTX, followed $5 \mathrm{~h}$ later by one injection of $10^{8}$ immune spleen cells, on tumor growth and survival time in mice bearing 4 -d tumors obtained after sub- cutaneous injection of either 3Cl-8 FLC or ESb cells. Confirming previous findings (32), CTX alone induced some inhibition of tumor growth in both these tumor models, although all the treated mice died from visceral metastases. Inoculation of immune spleen cells alone did not significantly affect the growth of FLC or ESb tumors. In contrast, the combined treatment with both CTX and immune spleen cells resulted in a strong synergistic antitumor response. In the representative experiments illustrated in Fig. 1, cure rates ranging from 100\% (FLC) to $37 \%(\mathrm{ESb})$ of the tumor-bearing mice were observed after the combined therapy. Spleen cells from normal mice did not increase the antitumor response to CTX (data not shown).

Fig. 2 illustrates some representative results obtained using an identical experimental protocol in mice bearing tumors de-

\section{$3 \mathrm{Cl}-8$}
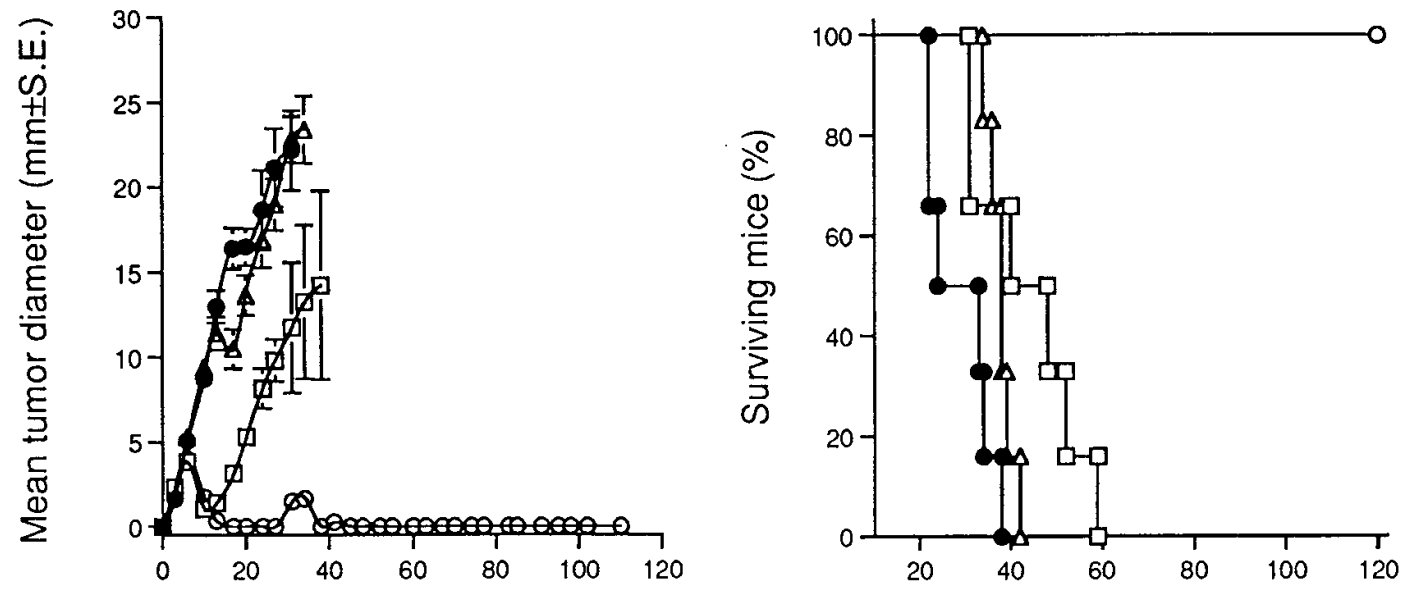

ESb


Figure 1. Effect of CTX and immune spleen cells on tumor growth and survival time in mice transplanted subcutaneously with $3 \mathrm{Cl}-8 \mathrm{FLC}(A)$ and ESb cells $(B)$. 6-7-wk-old male DBA/2 mice were injected subcutaneously with $2 \times 10^{6} 3 \mathrm{Cl}-8 \mathrm{FLC}$ or $2 \times 10^{5}$ ESb cells and divided into four groups. After $4 \mathrm{~d}$, two groups $(\square$ and $\bigcirc)$ were injected intraperitoneally with $0.5 \mathrm{ml}$ of CTX $(83 \mathrm{mg} / \mathrm{kg}) .5 \mathrm{~h}$ later, some mice $(\triangle$ and $\bigcirc)$ received an intravenous inoculum of $0.4 \mathrm{ml}$ of a suspension of $10^{8}$ immune splenocytes. There were six mice in each group. Tumor growth curve, left; survival time curve, right. Control, untreated mice $(\bullet)$; immune spleen cell-treated mice $(\triangle)$; CTX-treated mice $(\square)$; and mice treated with CTX and immune spleen cells $(\bigcirc)$. 



\section{p 11-R-Eb}


Figure 2. Effect of CTX and immune spleen cells on tumor growth and survival time in mice transplanted subcutaneously with Eb $(A)$ and p11R-Eb cells $(B)$. 6-7-wk-old male DBA/2 mice were injected subcutaneously with $2 \times 10^{6} \mathrm{p} 11$-R-Eb or $2 \times 10^{6}$ Eb cells and divided into four groups. After $4 \mathrm{~d}$, two groups $(\square$ and $\bigcirc)$ were injected intraperitoneally with $0.5 \mathrm{ml}$ of CTX $(83 \mathrm{mg} / \mathrm{kg}) .5 \mathrm{~h} \mathrm{later}$, some mice $(\triangle$ and $\bigcirc)$ received an intravenous inoculum of $0.4 \mathrm{ml}$ of a suspension of $10^{8}$ immune splenocytes. There were six mice in each group for $A$ and 6-8 mice for $B$. Tumor growth curve, left; survival time curve, right. Control, untreated mice $(\bullet)$; Immune spleen cell-treated mice, $\triangle$; CTX-treated mice, $\square$; mice treated with CTX and immune spleen cells $(\mathrm{O})$.

veloped after the injection of Eb or p11-R-Eb lymphoma cells. In these tumor models, we had previously failed to observe any therapeutic response to CTX alone, while the tumorinjected mice proved highly responsive to IL-2 therapy (32). Under the experimental conditions used in the experiments illustrated in Fig. 2, a single injection of CTX induced adverse effects. Indeed, CTX consistently shortened the survival time of the tumor-injected mice, even though apparently it did not affect subcutaneous tumor growth. Injection of the immune spleen cells induced only a partial antitumor response in mice transplanted with Eb cells, and it was completely ineffective in the animals bearing p11-R-Eb tumors. Notably, the sequential treatments with CTX and immune spleen cells resulted in an impressive antitumor response with cure rates ranging from $100 \%$ (Eb) to $50 \%$ (p11-R-Eb).

It was of interest to evaluate whether the combined regimen with CTX and immune spleen cells could also inhibit tumor growth in mice previously injected intravenously with highly metastatic tumor cells such as FLC, ESb, or p11-R-Eb cells. A single injection of CTX followed by inoculation of im- 


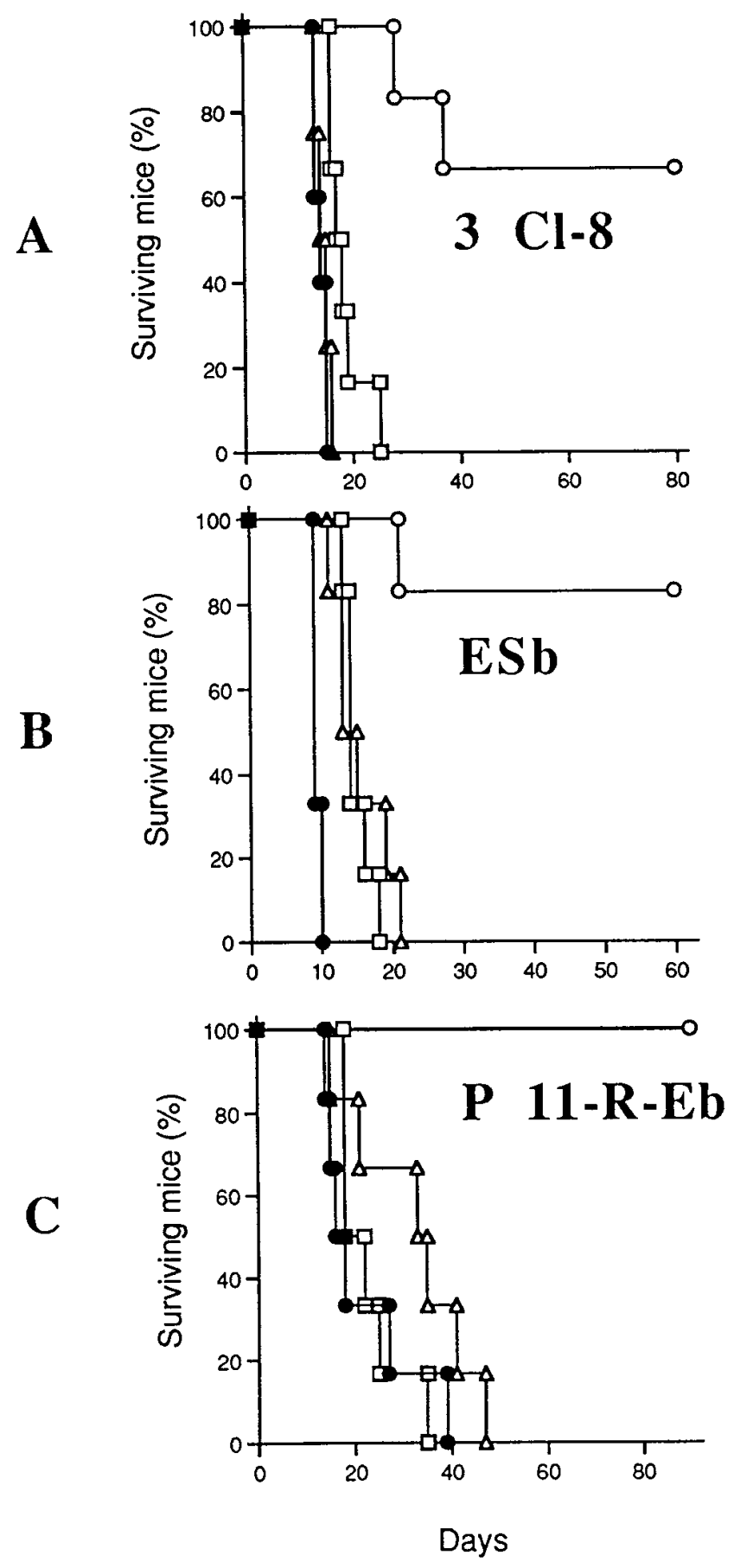

Figure 3. Effect of CTX and immune spleen cells on tumor growth and survival time in mice transplanted intravenously with 3Cl-8 FLC $(A), \mathrm{ESb}(B)$, and $\mathrm{p} 11-\mathrm{R}-\mathrm{Eb}(C)$ cells. 6-7-wk-old male DBA/2 mice were injected intravenously with $2 \times 10^{6} 3 \mathrm{Cl}-8 \mathrm{FLC}(A), 4 \times 10^{3} \mathrm{ESb}$ $(B)$, or $2 \times 10^{6} \mathrm{p} 11-\mathrm{R}-\mathrm{Eb}$ cells $(C)$ and divided into four groups. After $1 \mathrm{~d}$, two groups ( $\square$ and $\bigcirc$ ) were injected intraperitoneally with $0.5 \mathrm{ml}$ of CTX $(83 \mathrm{mg} / \mathrm{kg}) .5 \mathrm{~h}$ later, some mice $(\triangle$ and $\bigcirc)$ received an intravenous inoculum of $0.4 \mathrm{ml}$ of a suspension of $10^{8}$ immune splenocytes. There were at least six mice in each group. Control, untreated mice $(\bullet)$; immune spleen cell-treated mice $(\triangle)$; CTX-treated mice, $(\square)$; mice treated with CTX and immune spleen cells $(\bigcirc)$. mune cells strongly suppressed development of tumor metastases, resulting in a very high percentage (67-100\%) of surviving mice, while all the treated animals in the other groups died from visceral metastases, similarly to the mice in the corresponding control groups (Fig. 3).

Studies on the mechanisms involved in the synergistic response to CTX and immune spleen cells in mice bearing FLC tumors. The data reported above indicated that the sequential treatment with CTX and immune spleen cells resulted in an impressive synergistic response and tumor rejection in four different tumors transplantable in syngeneic DBA/2 mice. In an attempt to determine the possible mechanisms responsible for such a powerful antitumor response, studies were performed using 3Cl-8 FLC line because of the extensive information available on the in vivo behavior of these tumor cells and their response to different therapy regimens. This highly metastatic tumor has been used widely by our group for evaluating the antitumor response to type I IFN (44-47) and other cytokines, as well as to chemotherapy $(32,48-50)$. In particular, DBA/2 mice bearing metastatic FLC do not develop a clear antitumor response after treatment with various cytokines or chemotherapeutic agents, with the notable exception of type I IFN, which markedly inhibited tumor growth and visceral metastases $(41,48)$.

We report herein the results of several sets of experiments aimed at defining the mechanisms involved in generating the potent antitumor response observed in $\mathrm{DBA} / 2$ mice bearing FLC tumors and treated with CTX and immune spleen cells.

The synergistic antitumor response to CTX and immune spleen cells is not simply due to the acquired effectiveness of the immune spleen cells in animals with a reduced tumor burden as a result of the chemotherapeutic treatment. Before attempting to dissect the possible mechanisms involved in the synergistic response to CTX and immune spleen cells, it was important to ascertain that the antitumor effectiveness of the transferred splenocytes was not simply due to a reduced number of residual tumor cells after the chemotherapeutic treatment, which could result in enhanced antitumor activity via the transferred immune cells.

In previous studies, we outlined the highly reproducible relationship between the number of FLC injected intravenously into DBA/2 mice and the mean day of death of the injected animals (47). Fig. $4 \mathrm{~A}$ shows the results of a representative tumorigenicity assay. In a set of preliminary experiments, we had consistently noticed that in mice injected intravenously with $2 \times 10^{4} \mathrm{FLC}$, a single intravenous inoculation of CTX resulted in a mean increase of survival time versus the control mice of 4-5 d (mean day of death: $16.8 \pm 0.7$ vs. $12.8 \pm 0.3$ of untreated mice), corresponding to the survival time routinely observed in mice injected intravenously with $2 \times 10^{2}$ FLC. Thus, we inferred that under our experimental conditions, CTX induced an $\sim 100$-fold reduction in tumor burden. We then performed an experiment with the specific aim of evaluating whether the immune spleen cells could significantly suppress tumor growth in mice injected with $2 \times 10^{2}$ FLC (the number corresponding to the putative residual tumor burden after CTX treatment) together with $2 \times 10^{4}$ formalin-fixed FLC (which mimics the amount of residual dead cells available for immune stimulation in mice injected with $2 \times 10^{4}$ viable cells and treated with CTX). As shown in Fig. $4 \mathrm{~B}$, the immune cells induced only a marginal antitumor effect in mice coinjected with $2 \times 10^{2}$ viable FLC and $2 \times 10^{4}$ formalin-fixed cells, while injection of the 


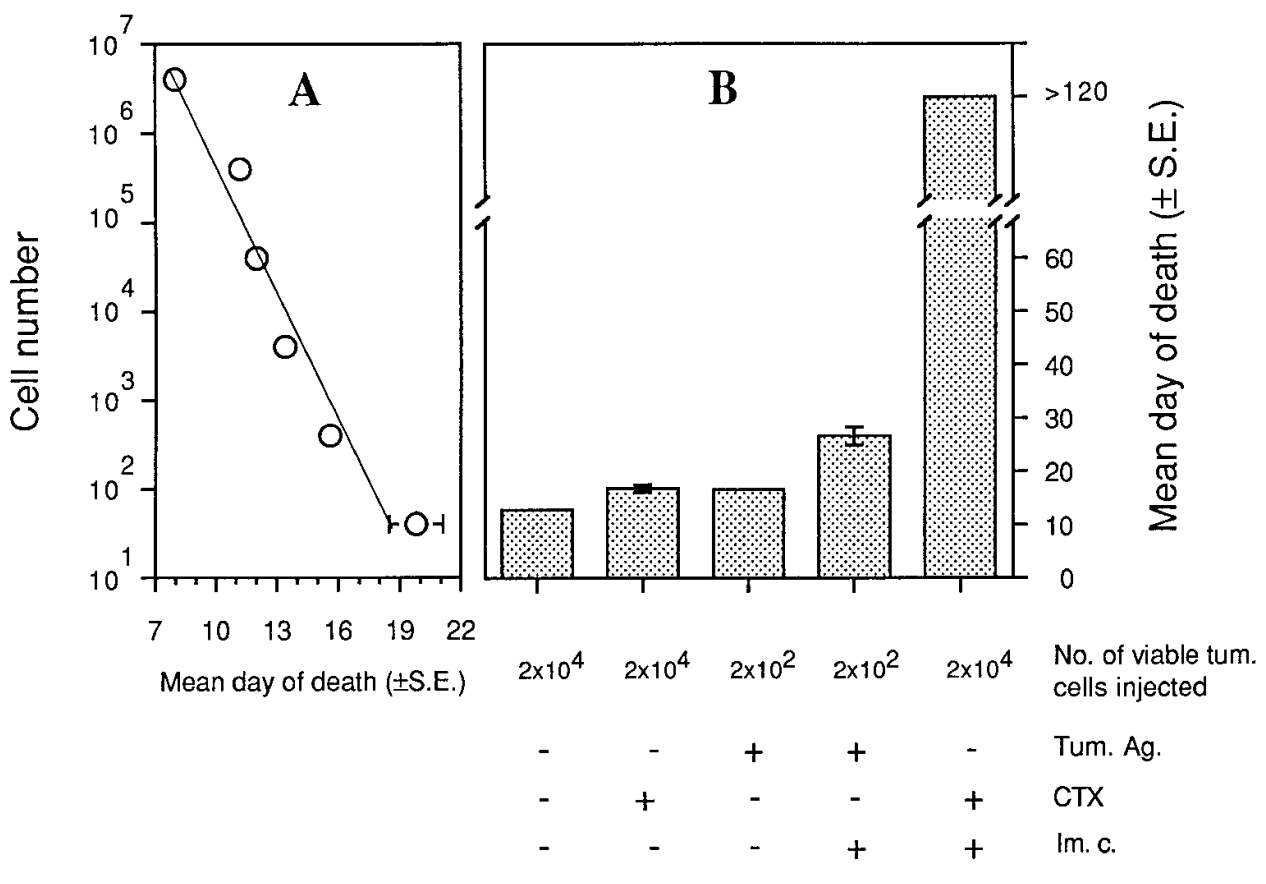

Figure 4. Effect of immune spleen cells on the survival time in mice transplanted intravenously with a number of tumor cells corresponding to that remaining after CTX treatment of FLC-injected mice. $A$ shows the correlation between the mean day of death and the number of FLC injected intravenously into $\mathrm{DBA} / 2$ mice. There were six mice per group. (B) 6-7-wk-old male DBA/2 mice were injected intravenously with $2 \times 10^{4}$ or $2 \times 10^{2} 3 \mathrm{Cl}-8$ FLC and divided into five groups. 1 $\mathrm{d}$ after tumor injection, two groups were injected intraperitoneally with $0.5 \mathrm{ml}$ of CTX $(83 \mathrm{mg} / \mathrm{kg}) .5 \mathrm{~h}$ later some mice received an intravenous inoculum of $0.4 \mathrm{ml}$ of a suspension of $10^{8}$ immune splenocytes, alone or in association with formalin-fixed 3Cl-8 FLC as indicated. There were six mice per group. same preparation of spleen cells in animals inoculated with $2 \times$ $10^{4}$ viable cells, but also treated with CTX, resulted in total suppression of tumor formation and cure of all the injected mice. Similar results were observed in a set of experiments performed in mice injected subcutaneously with FLC (data not shown). Thus, together these results indicated that the synergistic antitumor effects could not simply be explained by the low residual number of tumor cells after chemotherapy, but that host treatment with CTX was essential in order to achieve a clear-cut antitumor response after adoptive transfer of the immune spleen cells.

Development of a tumor-specific immunity in tumor-injected mice surviving after combined therapy. To investigate whether the combined therapy with CTX/immune cells induced tumor-

Table I. Development of an Antitumor-specific Memory in Mice Injected with 3Cl-8 FLC and Subjected to the Combined Therapy with CTX and Immune Spleen Cells

\begin{tabular}{llcc}
\hline \multicolumn{1}{c}{ Mice } & $\begin{array}{c}\text { Tumor } \\
\text { challenge }\end{array}$ & $\begin{array}{c}\text { No. of mice } \\
\text { with tumor/ } \\
\text { total no. of mice }\end{array}$ & $\begin{array}{c}\text { Day of death } \\
\text { (mean } \pm \text { SE) }\end{array}$ \\
\hline 3Cl-8-injected/cured* & $3 \mathrm{Cl}-8$ & $0 / 11^{\|}$ & $>60 \|$ \\
Control uninjected $^{\ddagger}$ & $3 \mathrm{Cl}-8$ & $4 / 4$ & $37.3 \pm 7.2$ \\
3Cl-8-injected/cured* $^{*}$ & p11-R-Eb & $9 / 9$ & $38.7 \pm 1.5$ \\
Control uninjected $^{\ddagger}$ & p11-R-Eb & $4 / 4$ & $29.3 \pm 0.8$
\end{tabular}

* Six 7-wk-old male DBA/2 mice were injected subcutaneously with $2 \times$ $10^{6} 3 \mathrm{Cl}-8$ cells and, after $4 \mathrm{~d}$, treated with CTX and immune spleen cells as indicated in Methods. All the mice in this group were tumor-free $123 \mathrm{~d}$ after tumor injection. At this time, the mice were divided in two groups and challenged with either $3 \mathrm{Cl}-8$ FLC or p11-R-Eb cells as indicated. ${ }^{\ddagger}$ Normal uninjected male DBA/2 of the same age were used as controls. $\S_{2} \times 10^{5}$ cells subcutaneously. ${ }^{\|}$Mice were scored for tumor formation and survival time for a period of $60 \mathrm{~d}$ after tumor challenge. specific immunity, the surviving FLC-injected mice were challenged $123 \mathrm{~d}$ after the original tumor injection with either homologous tumor cells or with the unrelated p11-R-Eb lymphoma. As shown in Table I, the mice cured after the combined therapy proved to be totally resistant to the subcutaneous challenge with FLC, but not to the injection of the unrelated tumor.

Characterization of the spleen cell population responsible for the synergistic antitumor response in mice treated with $C T X$. We then attempted to define which immune cells were responsible for the potent antitumor response observed in tumor-bearing mice pretreated with CTX. As shown in Table II,

Table II. Effect of In Vitro Depletion of T Lymphocytes on the Capacity of Immune Spleen Cells to Suppress Tumor Growth in Mice Transplanted Subcutaneously with 3Cl-8 FLC and Treated with CTX

\begin{tabular}{lcc}
\hline \multicolumn{1}{c}{ Treatment } & $\begin{array}{c}\text { No. of dead mice*/ } \\
\text { total no. of mice }\end{array}$ & $\begin{array}{c}\text { Day of death } \\
\text { (mean } \pm \text { SE) }\end{array}$ \\
\hline None & $11 / 11(100 \%)$ & $28.5 \pm 3.0$ \\
CTX + Im. c. & $0 / 17(0 \%)$ & $>100$ \\
CTX + Im. c. + compl. & $0 / 10(0 \%)$ & $>100$ \\
CTX + Im. c. + anti CD4 & $\underline{17 / 21(82 \%)^{\ddagger}}$ & ${\underline{50.6 \pm 2.5^{\S}}}^{>}$ \\
CTX + Im. c. + anti CD8 & $0 / 7(0 \%)$ & \\
\hline
\end{tabular}

Six 7-wk-old male DBA/2 mice were injected subcutaneously with $2 \times$ $10^{6} 3 \mathrm{Cl}-8 \mathrm{FLC}$. After $4 \mathrm{~d}$, some mice were injected intraperitoneally with $0.5 \mathrm{ml}$ of CTX $(83 \mathrm{mg} / \mathrm{kg})$ and, $5 \mathrm{~h}$ later, inoculated intravenously with $0.4 \mathrm{ml}$ of a suspension of $10^{8}$ undeplated or depleted immune splenocytes. In vitro depletion of $\mathrm{CD} 4+$ and $\mathrm{CD} 8+\mathrm{T}$ cells was performed as described in Methods. *The surviving mice were killed after $100 \mathrm{~d}$, and were found to be tumor-free. ${ }^{*}$ Calculated only for dead mice. ${ }^{\S}$ The significant values $(P<0.001)$ vs. all the other groups of mice treated with CTX and Im. c. are underlined. 
depletion of CD4+ T lymphocytes by in vitro incubation of the immune spleen cells with anti-CD4 monoclonal antibody and complement resulted in a marked loss of the antitumor effectiveness of the immune cells (when tested in tumor-bearing mice treated with CTX) compared with control splenocytes, undepleted immune cells treated with complement alone, or with CD8+-depleted cells, all of which were capable of inducing a full antitumor response.

Lack of evidence for a role of CTX in inhibiting some putative suppressor cells in tumor-bearing mice. The prevailing interpretation of the enhanced antitumor response to adoptive immunotherapy observed in several mouse models after CTX treatment is based on the assumption that this chemotherapeutic agent can selectively inhibit the generation and function of some suppressor cells that are thought to be induced after tumor transplantation (23-28). Thus, we first undertook a set of experiments to determine whether we could find any evidence of suppressor activity in spleen cells from mice bearing established FLC tumors. Fig. 5 shows the results of some representative experiments in which we tested whether the injection of $10^{8}$ splenocytes from DBA/2 mice bearing 15 -d sub-



Figure 5. Spleen cells from tumor-bearing mice do not suppress the effectiveness of the CTX/immune cell therapy. 6-7-wk-old male DBA $/ 2$ mice were injected subcutaneously with $2 \times 10^{6} 3 \mathrm{Cl}-8 \mathrm{FLC}$ and divided into different groups. As indicated, some groups were injected intraperitoneally with $0.5 \mathrm{ml}$ of CTX $(83 \mathrm{mg} / \mathrm{kg})$ and, $5 \mathrm{~h}$ later, were inoculated with $0.4 \mathrm{ml}$ of a suspension of $10^{8}$ splenocytes or left untreated. Spleen cell suspensions were obtained either from mice immunized with IFN $\alpha 1-\mathrm{Cl}-11$ FLC (Im. c.) or from mice injected subcutaneously with $2 \times 10^{5} 3 \mathrm{Cl}-8$-FLC $15 \mathrm{~d}$ before death (named "spleen cells from tumor-bearing mice", $S c-T B M$ ) and injected as indicated. The figure represents cumulative results of three different experiments. The coinjection of $10^{8}$ immune spleen cells or Sc-TBM with $10^{8}$ spleen cells from normal mice did not result in any significant change as compared with the groups of mice only infected with the immune cells or with the Sc-TBM. cutaneous FLC tumors could suppress the antitumor effectiveness of the immune cells in CTX-treated tumor-bearing mice. Coinjection of the spleen cells from tumor-bearing mice with the immune cells did not result in any impairment of the antitumor response observed in the control group of FLC-injected mice treated with CTX and inoculated with the immune spleen cells alone. Similar results were also obtained by coinjecting spleen cells from mice with 7-d tumors with immune cells (data not shown).

To further support these findings, a more direct approach was to see whether pretreatment with CTX followed by inoculation of immune cells a few days before tumor cell inoculation could also result in marked enhancement of the antitumor activity of the spleen cells themselves. Fig. $6 A$ shows the results obtained in the different treatment groups when pretreatment with CTX and immune cells was performed $6 \mathrm{~d}$ before tumor cell challenge. Notably, CTX markedly enhanced the antitumor effectiveness of the immune cells, but only when the latter were coinjected with formalin-fixed FLC. Fig. $6 B$ illustrates the degree of protection from the challenge with FLC when the mice were subjected to the combined regimen with CTX and immune cells together with formalin-fixed FLC at different days before tumor injection. A strong protection was only observed when the mice were injected with FLC $6 \mathrm{~d}$ after the CTX/immune cells treatments. A minor antitumor effect was detected when the tumor challenge was performed on day 10 .

Altogether, the data reported above suggest that the CTXinduced effectiveness of the immune spleen cells was independent of any possible drug effect on putative suppressor cells occurring in tumor-bearing mice.

Effects of CTX on the host environment and its possible relevance in determining the antitumor effectiveness of the immune spleen cells. The data described in Fig. 6 indicated that CTX somehow primed the mice for an efficient response to adoptive immunotherapy, rendering them highly susceptible to the antitumor activity of the immune spleen cells, provided that these cells were also stimulated by the simultaneous injection of tumor antigens (i.e., formalin-fixed FLC). These results, together with the finding that the injection of CTX after the transfer of the immune cells was ineffective (data not shown), suggested that, in this model, in vivo administration of CTX modified the host environment in such a way as to allow longterm survival, functional activity, and proliferation of the transferred immune lymphocytes.

It is known that one of the major events occurring in vivo a few days after CTX treatment is the so-called "rebound phenomenon" of white blood cells after drug-induced myelosuppression, which is thought to be accompanied by production of growth factors for progenitor cells $(37,38)$. Fig. $7 A$ illustrates the effects of a single injection of CTX in normal DBA/2 mice on the number of peripheral leukocytes or leukocyte subpopulation at different times after drug treatment. There was a clear-cut recovery from the CTX-induced suppressive effects, starting from days 4-5 after treatment. Similar rebound kinetics were observed after CTX injection of tumor-bearing mice (data not shown).

As shown in Fig. $7(B)$, there were high levels of thymidine incorporation in mixed cultures of spleen and bone marrow cells from either normal or tumor-bearing mice $3 \mathrm{~d}$ after CTX injection. This high proliferation capability was not maintained 6-10 d after CTX treatment. We then hypothesized that CTX could enhance the proliferation capability of the immune sple- 



Figure 6. Effects of the pretreatment with CTX and immune spleen cells on the challenge of DBA/2 mice with 3Cl-8 FLC. 6-7-wk-old male DBA $/ 2$ mice were injected intraperitoneally with $0.5 \mathrm{ml}$ of CTX $(83 \mathrm{mg} / \mathrm{kg})$ or left untreated. $5 \mathrm{~h}$ later, some mice were inoculated with $0.4 \mathrm{ml}$ of a suspension of $10^{8}$ immune spleen cells (Im.c) alone or mixed with $2 \times 10^{6}$ formalin-fixed 3Cl-8-FLC tumor cells (Tum. Ag.). Mice were challenged intravenously with $10^{3} 3 \mathrm{Cl}-8$-FLC at different days thereafter. $A$ shows the mean day of death of mice treated with various regimens (as indicated in the figure) $6 \mathrm{~d}$ before tumor cell injection. There were six mice per group. $B$ illustrates the effectiveness of the combined "CTX/immune cells/Ag regimen" when performed at different days before tumor cell challenge, as compared with untreated (Untr) 3Cl-8 FLC-injected controls. Bars indicate the mean day of death \pm SEM.Values above the bar indicate the number of surviving mice out of the total number. In the other groups, all the mice (six in each group) died from liver and spleen metastases. In a separate arm of the same experiment, immune cells induced tumor regression in six out of six mice bearing subcutaneous 4-d FLC tumors and treated with CTX, as described in Methods. $* P \leq 0.02$ vs. untreated control.

nocytes through a bystander effect, i.e., through release of soluble factors capable of enhancing proliferation, survival, and activity of the transferred lymphocytes. Therefore, we directly tested in vitro proliferation of splenocytes (untreated or stimulated with irradiated FLC) harvested from either normal or tumor-bearing mice at different times after in vivo administration of CTX, alone or in association with the subsequent transfer of the immune cells. The results presented in Fig. 8 clearly indicate that consistent levels of thymidine incorporation only occurred when we used tumor-stimulated splenocytes from CTX-treated mice, and particularly when the animals had also been inoculated with the immune spleen cells from immunized donor mice.

To determine whether soluble factors released from normal or tumor-bearing mice treated with CTX could sustain proliferation of the immune spleen cells, we then performed a set of experiments in which spleen and bone marrow cells from CTX-treated animals ("donor cells") were cocultivated for $5 \mathrm{~d}$ with immune splenocytes ("target cells") using a millipore membrane to separate the two-cell populations. As shown in Fig. 9, cocultivation of the immune cells with the donor cells from CTX-treated animals resulted in a clear-cut induction of proliferation in the target cells, thus indicating that soluble factors released by the cells of CTX-treated mice induced an active proliferation of the immune splenocytes. The proliferation-promoting effect was maximal when donor cells were harvested $3 \mathrm{~d}$ after CTX treatment. Normal spleen cells did not proliferate when cocultured with donor cells (data not shown).

Host components involved in the response of the recipient tumor-bearing mice to the combined therapy with CTX and immunotherapy. The data illustrated above indicated that CTX did not act by inhibiting some tumor-induced suppressor cells, but through bystander effects on the host environment, probably by the release of growth factors capable of inducing in vivo proliferation, long-term survival, and efficient activity of the transferred tumor-specific immune cells (i.e., CD4+ T cells). We then undertook a series of experiments aimed at evaluating to what extent some host cell components/factors in the recipient mice were involved in generating the potent antitumor response to the transfer of the immune cells after CTX treatment. Preliminary studies had shown that the combined therapy was totally ineffective when immunosuppressed (i.e., splenectomized, irradiated, and anti-asialo $\mathrm{GM}_{1}$-treated) nude 

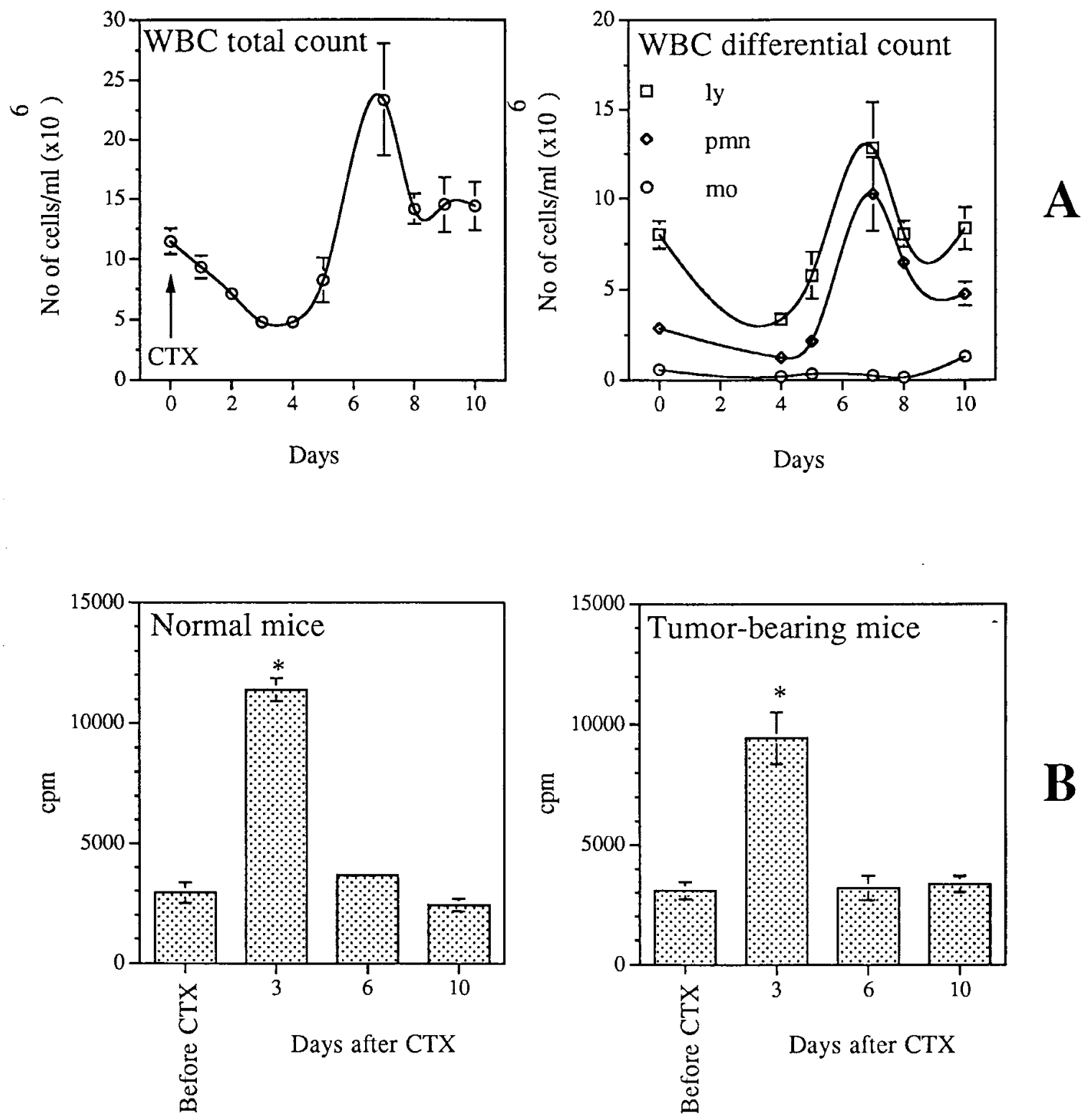

Figure 7. Effect of CTX on the number of WBC and on the in vitro proliferation of bone marrow and spleen cells from normal or 3Cl-8 FLCinjected mice at different times after CTX treatment. $(A)$ 6-7-wk-old male DBA $/ 2$ mice were inoculated intraperitoneally with CTX $(83 \mathrm{mg} / \mathrm{kg}$ ). Anesthetized animals were then bled by the tail at different time intervals, and WBC count was performed as described in Methods. $(B) 0.2 \mathrm{ml}$ of a suspension of $2 \times 10^{5}$ bone marrow and spleen cells (obtained from normal or tumor-bearing mice treated with CTX 3, 6, or 10 d before death) were plated in triplicate in a 96-well microtiter plate to which was added $\left[{ }^{3} \mathrm{H}\right]$ thymidine as described in Methods. After a 48-h incubation, cells were harvested and counted for $\left[{ }^{3} \mathrm{H}\right]$ thymidine incorporation. The cpm values of bone marrow and spleen cells from CTX-treated normal (left) or tumor-bearing (right) mice represent the mean \pm SEM of three individual mice tested in triplicate before or at different times after in vivo CTX administration. Tumor-bearing mice had been injected subcutaneously with $10^{5} 3 \mathrm{Cl}-8 \mathrm{FLC} 2 \mathrm{~d}$ before CTX treatment. * $P \leq 0.005$ vs. untreated control.

mice were used as recipient tumor-bearing animals. Subsequent studies showed that CTX and immune cells were also ineffective in inhibiting FLC tumor growth in untreated nude mice (data not shown). Of the possible host cell types/factors to be evaluated, we focused our attention on NK cells and IFN- $\alpha / \beta$ since they have been previously shown to play crucial roles in modulating the antitumor activity of immune spleen cells in the FLC tumor model (43). Moreover, recent studies had indicated that endogenous IFN- $\alpha / \beta$, produced in response to viral infection, was essential for proliferation and long-term survival of memory T cells (51). We then determined whether injection of either anti-asialo- $\mathrm{GM}_{1}$ antibodies or a potent preparation of type-I IFN antibodies could prevent the effectiveness of the combined therapy with immune cells in CTXtreated recipient mice. Injection of either anti-asialo- $\mathrm{GM}_{1}$ (Table III) or antibodies to IFN- $\alpha / \beta$ (Table IV) resulted in complete inhibition of the responses to the combined regimen with CTX and immunotherapy. 
Table III. The Antitumor Effect of Combined CTX-immune Cell Therapy Is Suppressed by Antiasialo $\mathrm{GM}_{-1}$ Antibody Injection Mice

\begin{tabular}{lcc}
\hline \multicolumn{1}{c}{ Treatment } & $\begin{array}{c}\text { No. of dead mice/ } \\
\text { total no. of mice }\end{array}$ & $\begin{array}{c}\text { Day of death* } \\
\text { (mean } \pm \text { SE) }\end{array}$ \\
\hline None & $7 / 7$ & $23.5 \pm 3.5$ \\
CTX & $7 / 7$ & $34.8 \pm 2.4$ \\
Im.c. & $7 / 7$ & $30.0 \pm 2.5$ \\
CTX + Im. c. & $2 / 12^{\ddagger}$ & \\
CTX + Im. c. + rabbit serum & $1 / 7^{\ddagger}$ & 52 \\
CTX + Im. c. + anti asialo GM- ${ }_{-1}$ & $7 / 7$ & $45.1 \pm 5.2$
\end{tabular}

Six 7-wk-old male DBA/2 mice were injected subcutaneously with $2 \times$ $10^{6} 3 \mathrm{Cl}-8 \mathrm{FLC}$. After $4 \mathrm{~d}$, some mice were injected intraperitoneally with CTX, and $5 \mathrm{~h}$ later were inoculated intravenously with $0.4 \mathrm{ml}$ of a suspension of $10^{8}$ immune spleen cells. Some mice were treated with 0.2 $\mathrm{ml}$ of a 1:10 dilution of antiasialo $\mathrm{GM}_{-1}$ antibodies or control rabbit serum on days $-1,+4,+9$, and +15 with respect to the injection of the immune splenocytes (day 0 ). * Calculated only for dead mice. ${ }^{\ddagger} P<0.01$ vs. all the other groups of mice.

\section{Discussion}

Several reports have shown a strong synergistic effect of combined therapy with CTX and immune T cells in inhibiting tumor growth in mice (8-22), and a few clinical trials are currently in course with cancer patients using similar chemoimmunotherapeutic strategies (29-31). In this study, we have
Table IV. The Antitumor Effect of Combined CTX-immune Cell Therapy Is Inhibited by Anti-IFN $\alpha / \beta$ Antibody Injection of Recipient Mice with Antibody to IFN $\alpha / \beta$

\begin{tabular}{lcc}
\hline \multicolumn{1}{c}{ Treatment } & $\begin{array}{c}\text { No. of dead mice/ } \\
\text { total no. of mice }\end{array}$ & $\begin{array}{c}\text { Day of death } \\
\text { (mean } \pm \text { SE) }\end{array}$ \\
\hline None & $6 / 6$ & $14.5 \pm 0.8$ \\
Anti IFN $\alpha / \beta$ & $6 / 6$ & $13.2 \pm 0.6$ \\
CTX & $6 / 6$ & $18.8 \pm 2.1$ \\
Im.c. & $6 / 6$ & $15.1 \pm 0.1$ \\
CTX + Im. c. + anti IF $\alpha / \beta$ & $6 / 6$ & $14.6 \pm 0.4$ \\
CTX + Im. c. & $3 / 6^{\ddagger}$ & $33.0 \pm 5.0^{*}$
\end{tabular}

Six 7-wk-old male DBA/2 mice were injected intravenously with $2 \times$ $10^{4} 3 \mathrm{Cl}-8 \mathrm{FLC}$. After 1d, some mice were injected intraperitoneally with CTX, and $5 \mathrm{~h}$ later were inoculated intravenously with $0.4 \mathrm{ml}$ of a suspension of $10^{8}$ immune spleen cells. Some mice were also injected with antibodies to mouse IFN $\alpha / \beta\left(\sim 2 \times 10^{5}\right.$ neutralizing units per mouse) on days -2 (intravenous), 0 (intraperitoneal), +4 (intraperitoneal), +12 (intraperitoneal) with respect to the injection of the immune splenocytes (day 0 ). ${ }^{*}$ Calculated only for dead mice. ${ }^{\ddagger} P<0.01$ vs. all the other groups of mice.

provided additional data on the powerful antitumor activity that can be generated after a combined CTX/immunotherapy regimen in mice transplanted with four syngeneic tumors, exhibiting a different response to CTX alone. Notably, treatment with CTX and immune spleen cells resulted in the cure of the majority of mice bearing subcutaneous or intravenous metastatic tumors (Figs. 1-3). A remarkable antitumor response
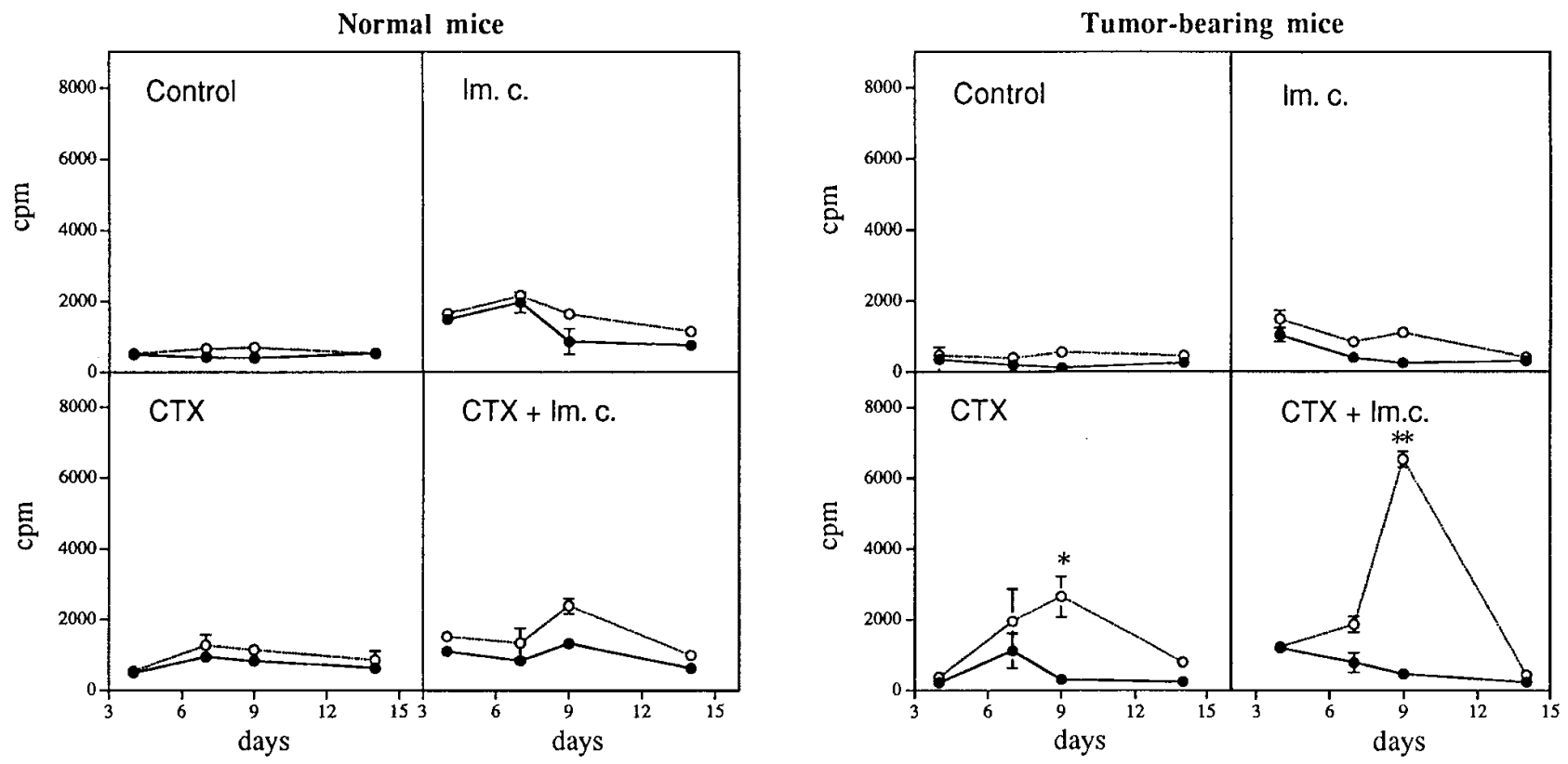

Figure 8. In vitro proliferation of splenocytes from 3Cl-8 FLC tumor-bearing mice treated with CTX (alone or followed by immune cell injection) at different times after tumor inoculation. 6-7-wk-old male DBA/2 mice were injected subcutaneously with $10^{5} 3 \mathrm{Cl}-8 \mathrm{FLC}(B)$ or left uninjected and divided $(A)$ into four groups. $8 \mathrm{~d}$ later, some mice were inoculated intraperitoneally with CTX (alone or followed by an intravenous inoculation of $10^{8}$ immune spleen cells ( $\mathrm{Im}$. c.), or with immune cells alone, as indicated in the figure. 4, 7, 9, and $14 \mathrm{~d}$ after treatment, three mice per group were killed, and the spleen cells were tested in vitro alone $(\bullet)$ or mixed with irradiated $3 \mathrm{Cl}-8$ FLC tumor cells $(\bigcirc)$, for $\left[{ }^{3} \mathrm{H}\right]$ thymidine incorporation, as described in Methods. Values are expressed as mean \pm SEM of three individual mice tested in duplicate. In a separate arm of the same experiment, immune cells induced tumor regression in 5 out of 5 mice treated with CTX and inoculated subcutaneoulsy with $2 \times 10^{6}$ 3Cl-8 FLC, as described in Methods. ${ }^{*} P \leq 0.01 ;{ }^{\ddagger} P \leq 0.0001$ vs. spleen cells alone. 

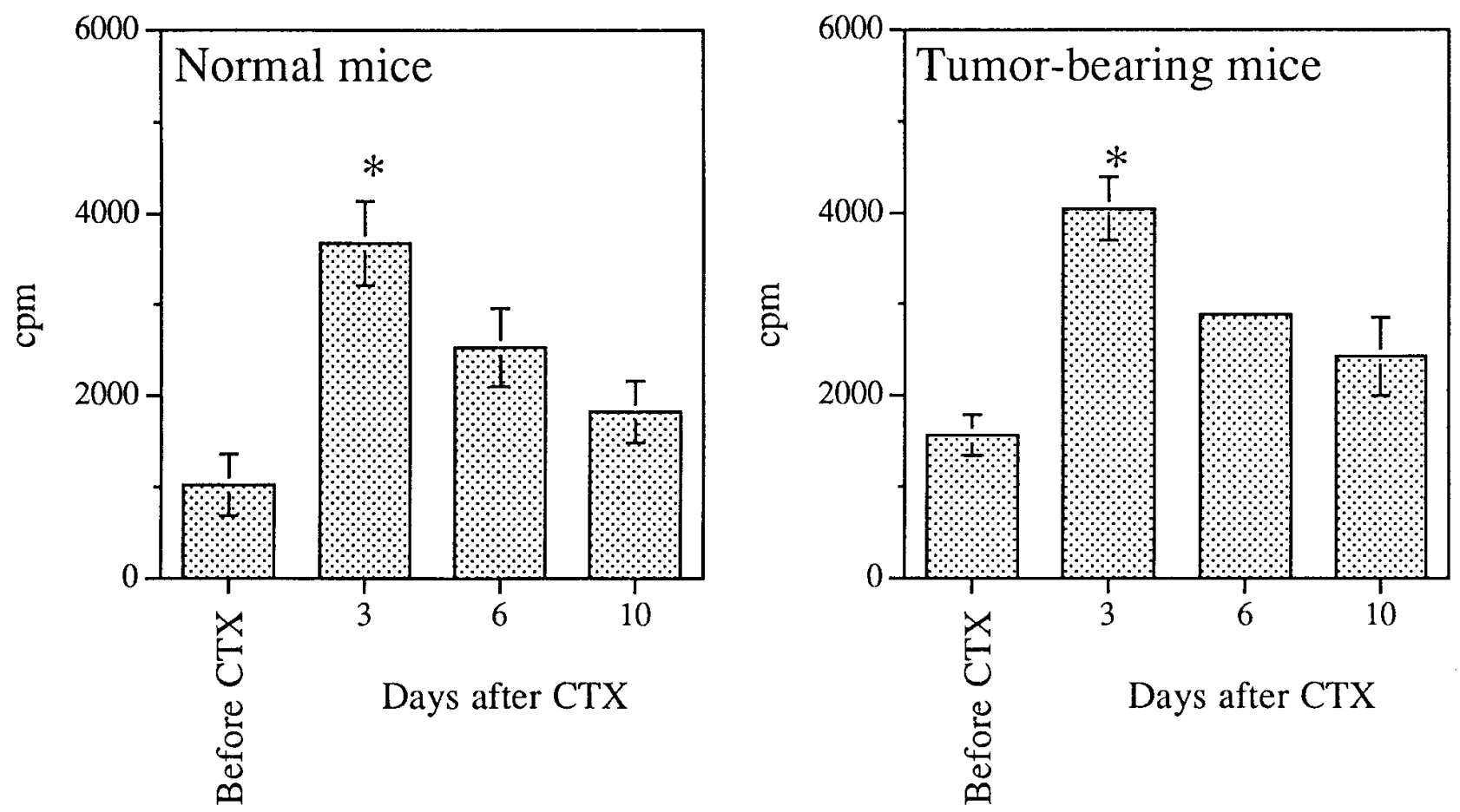

Figure 9. $\left[{ }^{3} \mathrm{H}\right]$ thymidine incorporation of immune splenocytes cocultivated in absence of cell-to-cell contact with bone marrow and spleen cells from 3Cl-8 FLC tumor-bearing mice at different times after CTX treatment. $1 \mathrm{ml}$ of a suspension of $10^{6}$ spleen cells from mice immunized with IFN $\alpha 1-\mathrm{Cl}-11$ FLC was plated onto a 24-well plate and cocultivated through a semipermeable membrane with $1 \mathrm{ml}$ of a suspension of $10^{6}$ bone marrow and spleen cells obtained from normal $(A)$ or tumor-bearing $(B)$ mice treated with CTX 3,6 , or $10 \mathrm{~d}$ before death. After $5 \mathrm{~d}$ of coculture, the single cell suspensions were harvested, divided into aliquots of $0.2 \mathrm{ml}$, and plated in triplicate in a 96-well microtiter plate for thymidine incorporation as described in Methods. The values represent incorporation cpm of immune spleen cells cocultivated through a semipermeable membrane with bone marrow and spleen cells from CTX-treated normal (left) or tumor-bearing (right) mice, before or at different days after in vivo CTX administration. Values are expressed as mean \pm SEM of three individual mice tested in triplicate. In a separate arm of the same experiment, immune cells induced tumor regression in five out of five mice treated with CTX and inoculated subcutaneously with $2 \times 10^{6} 3 \mathrm{Cl}-8 \mathrm{FLC}$ as described in Methods. Tumor-bearing mice had been injected subcutaneously with $10^{5} 3 \mathrm{Cl}-8 \mathrm{FLC} 2 \mathrm{~d}$ before CTX treatment. *P $\leq 0.01$ vs. untreated control.

and regression to the combined therapy was also observed in mice transplanted with tumors in which CTX alone had a clear-cut adverse effect, while immune cells only marginally affected tumor growth (Fig. 2). In this study, we also analyzed the mechanisms involved in the generation of this potent antitumor response, focusing our attention on one particular tumor model, the FLC system.

The mechanisms by which CTX can synergize with immunotherapy are still a matter of debate $(17,18)$. Reduction of tumor burden as well as inhibition of suppressor cell activities (thought to prevent the antitumor functions of the intravenous infused tumor-sensitized T cells) have been suggested as possible explanations for these synergistic effects (18). The results presented in this article, however, indicate the existence of different previously unidentified mechanisms that may explain the synergistic effects of CTX and immune spleen cells. Part of the evidence for these mechanisms is based on experimental exclusion of the involvement of previously considered mechanisms. In fact, our data indicate that reduction of tumor burden by CTX does not play any relevant role in inducing an antitumor response to immunotherapy (Fig. 4). In addition, in all our experiments, no evidence for the presence of cell suppressor activity was found using spleen cells from tumor bearing mice (Fig. 5), thus strongly suggesting that CTX does not act by inhibiting $\mathrm{T}$ suppressor cells in our experimental model. Notably, however, CTX doses lower than those used in our experiments were used in the studies reporting a CTX effect on T suppressor cells (24). Experiments aimed at defining the relevant spleen cell population(s) responsible for synergistic antitumor effects revealed that CD4+ T cells were the important cell components (Table II), even though CD8+ T cells cannot be excluded as in vivo effector cell population in recipient mice. The finding that the combined therapy was not effective in immunosuppressed nude mice or in mice depleted of the NK cells activity (Table III) indicate that the transferred immune cells acted through recruitment/generation of other host effector functions/mechanisms.

The results discussed above raised one major question: how can these immune CD4+ T cells determine such a powerful antitumor response in CTX-pretreated tumor-bearing mice? The results of a set of experiments illustrated in Fig. 6, in which we pretreated the mice with CTX and subsequently with immune cells before tumor cell injection, shed some light on this issue. In particular, the finding that a strong antitumor response was observed when metastatic parental cells were injected in mice pretreated ( $6 \mathrm{~d}$ before) with CTX and immune spleen cells (in the presence of tumor antigen) underscores two important points: $(a)$ it further excludes any important role of 
a drug-mediated reduction in tumor burden, as well as of a CTX-induced inhibition of tumor-elicited T cell suppressor activity; and (b) it implies that CTX, even in the absence of a growing tumor, can induce host changes or key factors capable of conferring a powerful antitumor activity to the adoptively transferred immune spleen cells. This finding leads to the question of how the CTX-induced host environment can allow strong antitumor activity of the immune $\mathrm{T}$ cells. The data shown in Figs. 7-9 indicate that host cells from CTX-treated mice can confer a proliferative activity to immune spleen $\mathrm{T}$ cells, but not to normal spleen cells, in both an aspecific (Fig. 7 and 9) and a tumor-specific (Fig. 8) manner, which may result in an increase of their antitumor activity in vivo.

Although the notion that CTX can induce release of cytokines and growth factors during the rebound events after druginduced myelosuppression is well-documented (52), this fact has not been considered, to the best of our knowledge, as a possible explanation for the effectiveness of adoptive immunotherapy after CTX treatment. Several data are available on the long-term persistence of T cells, especially in mice, and cytokines are thought to play a pivotal role in the survival and proliferation of these cells (53-56). Likewise, bystander effects (i.e., the production of cytokines, particularly of type I IFN) in the course of infectious diseases have been recently considered responsible for sustaining the in vivo proliferation and longterm survival of memory CD8 $+\mathrm{T}$ cells $(51)$. The finding that antibodies to IFN- $\alpha / \beta$ markedly inhibit the response of the recipient tumor-bearing mice to the combined therapy (Table IV) underlines the importance of these cytokines in sustaining antitumor activity of the transferred immune cells, and is in agreement with previous results for the FLC tumor model (43).

In conclusion, our data strongly suggest that CTX induces release of soluble factors that can enhance the proliferation, differentiation, and activity of tumor-specific immune $\mathrm{T}$ cells. These results could lead to a general reinterpretation of the synergistic effects of CTX and immunotherapy observed by others in experimental models (8-22), generally assumed to be mediated by effects on suppressor $\mathrm{T}$ cells. The data reported in this article may have more general implications on the relationships between the homeostatic mechanisms generated as a consequence of events perturbing the lymphohemopoietic equilibrium and the survival, expansion, and differentiation of immune cells endowed with a given T cell repertoire. Notably, a strong synergistic effect was also observed in the FLC system when the recipient mice were treated with sublethal does of $\gamma$-rays before the transfer of immune splenocytes (data not shown).

Lastly, these data provide a new rationale for combining certain chemotherapeutic agents and adoptive immunotherapy (mostly based on the knowledge of the time-dependent drug-induced modifications in the microenvironment and of their crucial importance in affecting the proliferation, longterm survival and functional activity of the transferred immune cells). Furthermore, these data might provide important insights on how we should sequentially treat cancer patients in order to achieve an optimal clinical response to combined chemoimmunotherapy.

\section{Acknowledgments}

We are grateful to Dr. Ion Gresser (Villejuif, France) for providing us with the sheep antibody to mouse IFN- $\alpha / \beta$, and for the helpful discus- sion and suggestions. We thank Ms. A. Ferrigno and A.M. Fattapposta for the secretarial aid, and Dr. Gael Ayers for linguistic revision.

This work was supported in part by grants from the Associazione Italiana Ricerca sul Cancro (Milan), Special Project on Gene Therapy, and Italy-USA Program on Therapy of Tumors.

\section{References}

1. Shu, S., T. Chou, and S.A. Rosemberg. 1986. In vitro sensitization and expansion with viable tumor cells and interleukin-2 in the generation of specific therapeutic effector cells. J. Immunol. 136:3891-3898.

2. Osband, M.E., P.T. Lavin, R.K. Babayan, S. Graham, D.L. Lamm, B. Parker, I. Sawczuk, S. Ross, and R.J. Krane. 1990. Effect of autolymphocyte therapy on survival and quality of life in patients with metastatic renal-cell carcinoma. Lancet. 335:994-998.

3. Mulè, J.J., S. Shu, L. Schwartz, and S.A. Rosemberg. 1984. Adoptive immunotherapy of established pulmonary metastases with LAK cells and recombinant interleukin-2. Science. 225:1487-1489.

4. Greenberg, P.D, D.E. Kern, and M.A. Cheever. 1985. Therapy of disseminated murine leukemia with cyclophosphamide and immune Lyt $-1^{+} 2^{-} \mathrm{T}$ Cells. J. Exp. Med. 161:1122-1134.

5. Yoshizawa, H., K. Sakai, A.E. Chang, and S. Shu. 1991. Activation by anti-CD3 of tumor-draining lymph node cells for specific adoptive immunotherapy. Cell. Immunol. 134:473-479.

6. Gold, J.E., and M.E. Osband. 1994. Autolymphocyte therapy. I. In vivo tumour-specific adoptive cellular therapy of murine melanoma and carcinoma using ex vivo activated memory T-lymphocytes. Eur. J. Cancer. 30:1871-1882.

7. Hill, D.L. 1975. A Review of Cyclophosphamide. CC. Thomas, Springfield, IL.

8. Radov, L.A., J.S. Haskill, and J.H. Korn. 1976. Host immune potentiation of drug responses to a murine mammary adenocarcinoma. Int. J. Cancer. 17:773-779.

9. Kolb, J.P, M.F. Poupon, G.M. Lespinats, D. Sabolovic, and F. Loisillier. 1977. Splenic modification induced by cyclophosphamide in $\mathrm{C} 3 \mathrm{H} / \mathrm{He}$, nude, and "B" mice. J. Immunol. 118:1595-1599.

10. Schwartz, A., P.W. Askenase, and R.K. Gershon. 1978. Regulation of delayed-type hypersensitivity reactions by cyclophosphamide-sensitive T-cells. J. Immunol. 121:1573-1577.

11. Hengst, J.C.D., M.B. Mokyr, and S. Dray. 1980. Importance of timing in cyclophosphamide therapy of MOPC-315 tumor-bearing mice. Cancer Res. 40: 2135-2141.

12. Vidovic, D., M. Marusic, and F. Culo. 1982. Interference of anti-tumor and immunosuppressive effects of cyclophosphamide in tumor-bearing rats. Cancer Immunol. Immunother. 14:36-40.

13. Turk, J.L., and D. Parker. 1982. Effect of cyclophosphamide on immunological control mechanism. Immunol. Rev. 65:99-113.

14. Kedar, E., R. Ben-Aziz, E. Epstein, and B. Leshem. 1989. Chemoimmunotherapy of murine tumors using interleukin-2 (IL-2) and cyclophosphamide. Cancer Immunol. Immunother. 29:74-78.

15. Katsanis, E., M.A. Bausero, A.C. Ochoa, C.M. Loeffler, B.R. Blazar, A.S. Leonard, and P.M. Anderson. 1991. Importance in timing of cyclophosphamide on the enhancement of interleukin-2-induced cytolysis. Cancer Immunol. Immunother. 34:74-78.

16. Laude, M., K.L. Russo, M.B. Mokyr, and S. Dray. 1993. Cure of mice bearing a late-stage, highly metastatic, drug-resistant tumor by adoptive chemoimmunotherapy. Cancer Immunol. Immunother. 36:220-236.

17. Evans, R. 1983. Combination therapy by using cyclophosphamide and tumor-sensitized lymphocytes: a possible mechanism of action. J. Immunol. 130 2511-2513.

18. Mitchell, M.S. 1989. Combining chemotherapy with biological response modifiers in treatment of cancer. J. Natl. Cancer Inst. 80:1445-1450.

19. Ootsu, K., K. Gotoh, and T. Houkan. 1989. Therapeutic efficacy of human recombinant interleukin-2 (TGP-3) alone or in combination with cyclophosphamide and immunocompetent cells in allogeneic, semisyngeneic, and syngeneic murine tumors. Cancer Immunol. Immunother. 30:71-86.

20. Kedar, E., Y. Rutkowski, and B. Leshem. 1992. Chemo-immunotherapy of murine solid tumors: enhanced therapeutic effects by interleukin- 2 combined with interferon $\alpha$ and the role of specific T cells. Cancer Immunol. Immunother. 35:63-68.

21. Gold, J.E., D.T. Zachary, and M.E. Osband. 1994. Adoptively transferred ex vivo activated memory T cells with cyclophosphamide: effective tumor-specific chemoimmunotherapy of advanced metastatic murine melanoma and carcinoma. Clin. Immunol. Immunopathol. 73:115-122.

22. Gold, J.E., D.T. Zachary, and M.E. Osband. 1995. Adoptive transfer of ex vivo-activated memory T-cell subsets with cyclophosphamide provides effective tumor-specific chemoimmunotherapy of advanced metastatic murine melanoma and carcinoma. Int. J. Cancer. 61:580-586.

23. Glaser, M., and M. Awwad. 1979. Regulation of specific cell-mediated cytotoxic response against SV40 induced tumour associated antigens by deple- 
tion of suppressor T-cells with cyclophosphamide in mice. J. Exp. Med. 149: 774-779.

24. Awwad, M., and R.J. North. 1988. Cyclophosphamide (Cy)-facilitated adoptive immunotherapy of a Cy-resistant tumour. Evidence that $\mathrm{Cy}$ permits the expression of adoptive T-cell mediated immunity by removing suppressor $\mathrm{T}$ cells rather than by reducing tumour burden. Cancer Res. 49:1649-1654.

25. Reissmann, T., R. Voegeli, J. Pohl, and P. Hilgard. 1989. Augmentation of host antitumor immunity by low doses of cyclophosphamide and mafosfamide in two animal tumor models. Cancer Immunol. Immmunother. 28:179-184.

26. North, R.J., and M. Awwad. 1990. Elimination of cycling CD4+ suppressor $\mathrm{T}$ cells with an anti-mitotic drug releases non-cycling CD8+ T cells to cause regression of an advanced lymphoma. Immunology. 71:90-95.

27. Hoover, S.K., S.K. Barret, T.M.T. Turk, T.C. Lee, and H.D. Bear. 1990. Cyclophosphamide and abrogation of tumor-induced suppressor $\mathrm{T}$ cell activity. Cancer Immunol. Immunother. 31:121-127.

28. Rakhmilevich, A.L., and R.J. North. 1994. Elimination of CD4+ T cells in mice bearing an advanced sarcoma augments the antitumor action of interleukin-2. Cancer Immunol. Immunother. 38:107-112.

29. Gold, J.E., S.D. Ross, D.J. Krellenstein, F. LaRosa, S.C. Malamud, and M.E. Osband. 1995. Adoptive transfer of ex vivo activated memory T-cells with or without cyclophosphamide for advanced metastatic melanoma: results in 36 patients. Eur. J. Cancer. 31A:698-708.

30. Gold, J.E., S.C. Malamud, F. LaRosa, and M.E. Osband. 1993. Adoptive chemoimmunotherapy using ex vivo activated memory T-cells and cyclophosphamide; tumor lysis syndrome of a metastatic soft tissue sarcoma. Am. J. Hematol. 44:42-47.

31. Abrams, J.S., J.L. Eiseman, T.J. Melink, R. Sridhara, D.J. Hiponia, M.M. Bell, C.P. Belani, W.H. Adler, and J. Aisner. 1993. Immunomodulation of interleukin-2 by cyclophosphamide: a phase IB trial. J. Immunother. 14:56-64.

32. Greco, G., L. Gabriele, C. Rozera, M. Venditti, F. Belardelli, and E. Proietti. 1995. Correlation between the sensitivity or resistance to IL-2 and the response to cyclophosphamide of 4 tumors transplantable in the same murine host. Int. J. Cancer. 61:1-7.

33. Puddu, P., C. Locardi, P. Sestili, F. Varano, C. Petrini, A. Modesti, L. Masuelli, I. Gresser, and F. Belardelli. 1991. Human immunodeficiency virus (HIV)-infected tumor xenografts as an in vivo model for antiviral therapy: role of $\alpha / \beta$ interferon in restriction of tumor growth in nude mice injected with HIVinfected U937 tumor cells. J. Virol. 65:2245-2253.

34. Affabris, E., C. Jemma, and G.B. Rossi. 1982. Isolation of interferonresistant variants of Friend erythroleukemia cells: effect of interferon and ouabain. Virology. 120:441-446.

35. Schirrmacher, V., G. Shantz, K. Clauer, D. Komitowski, H.P. Zimmermann, and M.L. Lohmann-Matthes. 1979. Tumor metastases and cell-mediated immunity in a model system in DBA/2 mice. I. Tumor invasiveness in vitro and metastasis formation in vivo. Int. J. Cancer. 13:147-162.

36. Gabriele, L., E. Proietti, G. Greco, M. Venditti, I. Gresser, V. Schirrmacher, P. Von Hoegen, U. Testa, A. Modesti, and F. Belardelli. 1995. Isolation and characterization of a metastatic Eb-Like tumor variant highly responsive to IL-2 and to combination cytokine therapy (IL2/IL-1 beta and IL-1 beta/IFN alpha/beta). Invasion Metastasis. 13:147-162.

37. Proietti, E., E. Tritarelli, L. Gabriele, U. Testa, G. Greco, E. Pelosi, M. Gabbianelli, F. Belardelli, and C. Peschle. 1993. Combined IL-1ß/IL-2 treatment in mice: synergistic myelostimulatory activity and protection against cyclophosphamide-induced myelosuppression. Cancer Res. 53:569-576.

38. Tritarelli, E., G. Greco, U. Testa, F. Belardelli, C. Peschle, and E. Proietti. 1994. Combined Interleukin-I $\beta /$ Interleukin-6 treatment in mice: synergistic myelostimulatory activity and myelorestorative effect after cyclophosphamideinduced myelosuppression. Cancer Res. 54:6469-6476.

39. Ferrantini, M., E. Proietti, L. Santodonato, L. Gabriele, M. Peretti, I. Plavec, F. Meyer, T. Kaido, I. Gresser, and F. Belardelli. 1993. $\alpha 1$-interferon gene transfer into metastatic Friend leukemia cells abrogated tumorigenicity in immunocompetent mice: antitumor therapy by means of interferon-producing cells. Cancer Res. 53:1107-1112.

40. Ciolli, V., L. Gabriele, P. Sestili, F. Varano, E. Proietti, I. Gresser, U. Testa, E. Montesoro, D. Bulgarini, G. Mariani, et al. 1991. Combined IL-1/IL-2 therapy of mice injected with highly metastatic Friend leukemia cells: host antitumor mechanisms and marked effects on established metastases. J. Exp. Med. 173:313-322.

41. Gresser, I., C. Maury, C. Carnaud, E. De Mayer, M.T. Manoury, and F. Belardelli. 1990. Antitumor effects of interferon in mice injected with interferon-sensitive and interferon-resistant Friend erythroleukemia cells. VIII. Role of the immune system in the inhibition of visceral metastases. Int. J. Cancer. 46:468-474.

42. Gresser, I., M.G. Tovey, M.-T. Bandu, C. Maury, and D. Brouty-Boyé 1976. Role of interferon in the pathogenesis of virus diseases in mice as demonstrated by the use of anti-inteferon serum. I. Rapid evolution of encephalomyocarditis virus infection. J. Exp. Med. 144:1305-1310.

43. Gresser, I., C. Maury, T. Kaido, M.G. Tovey, M.T. Maunoury, S. Gessani, G. Greco, and F. Belardellli. 1995. The essential role of endogrnous IFN $\alpha / \beta$ in the antimetastatic action of sensitized $\mathrm{T}$ lymphocytes in mice injected with Friend erythroleukemia cells. Int. J. Cancer. 63:726-731.

44. Gresser, I., T. Kaido, C. Maury, D. Woodrow, J. Moss, and F. Belardelli. 1994. Interaction of IFN $\alpha / \beta$ with host cells essential to the early inhibition of Friend erythroleukemia visceral metastases in mice. Int. J. Cancer. 57:604-611.

45. Belardelli, F., I. Gresser, C. Maury, and M.T. Maunoury. 1982. Antitumor effects of interferon in mice injected with interferon-sensitive and interferon-resistant Friend leukemia cells. II. Role of host mechanisms. Int. J. Cancer. 31:821-825.

46. Gresser, I., C. Carnaud, C. Maury, P. Eid, D. Woodrow, M.T Maounoury, and F. Belardelli. 1991. Host humoral and cellular mechanisms in the continued suppression of Friend erythroleukemia metastases after interferon $\alpha / \beta$ treatment in mice. J. Exp. Med. 173:1193-1203.

47. Gresser, I., C. Maury, D. Woodrow, J. Moss, M.G. Grütter, F. Vignaux, F. Belardelli, and M.T. Maunoury. 1988. Interferon treatment markedly inhibits the development of tumor metastases in the liver and spleen and increases survival time of mice after intravenous inoculation of Friend erythroleukemia cells. Int. J. Cancer. 41:135-142.

48. Belardelli, F., L. Gabriele, E. Proietti, P. Sestili, E. Peretti, C. Rozera, and I. Gresser. 1991. Synergistic antitumor effects of combined IL-1/IFN $\alpha / \beta$ therapy in mice injected with metastatic Friend erythroleukemia cells. Int. J. Cancer. 49:274-278.

49. Belardelli, F., E. Proietti, V. Ciolli, P. Sestili, G. Carpinelli, M. Di Vito, A. Ferretti, D. Woodrow, D. Boraschi, and F. Podo. 1989. IL-1 beta induces early metabolic and morphologic changes in transplantable mouse tumors. Similarities with the antitumor effects of TNF alpha or beta. Int. J. Cancer. 44:116-123.

50. Belardelli, F., V.Ciolli, U. Testa, E. Montesoro, D. Bulgarini, E. Proietti, P. Borghi, P. Sestili, C. Locardi, C. Peschle, and I. Gresser. 1989. Antitumor effects of IL-2 and IL-1 in mice transplanted with different syngeneic tumors. Int. J. Cancer. 44:1108-1116.

51. Tough, F.D., P. Borrow, and J. Sprent. 1996. Induction of bystander T cell proliferation by viruses and type I interferon in vivo. Science. 272:19471950.

52. Testa, U., R. Martucci, S. Rutella, G. Scambia, S. Sica, P. Benedetti Panici, L. Pierelli, G. Menichella, G. Leone, S. Mancuso, and C. Peschle. 1994 Autologous stem cell transplantation: release of early and late acting growth factors relates with hematopoietic ablation and recovery. Blood. 84:3532-3539.

53. Unutmaz, D., P. Pileri, and S. Abrignani. 1994. Antigen-independent activation of naive and memory resting T cells by a cytokine combination. J. Exp. Med. 180:1159-1164

54. Rocha, B.B. 1987. Population kinetics of precursors of IL 2-producing peripheral $\mathrm{T}$ lymphocytes evidence for short life expectancy. Continuous renewal, and post-thymic expansion. J. Immunol. 19:905-911.

55. Rocha, B., N. Dautigny, and P. Pereira. 1989. Peripheral T lymphocytes: expansion potential and homeostatic regulation of pool sizes and CD4/CD8 ratios in vivo. Eur. J. Immunol. 9:905-911.

56. Gold, J.E., and M.E. Osband. 1994. Autolymphocyte therapy. II. Dependence of in vivo anti-tumor specificity and long-term immunity against murine melanoma and carcinoma on ex vivo activated donor memory T-cells. Clin. Immunol. Immunopathol. 71:325-332. 